Scientia Militaria vol 40, no 3, 2012, pp.354-397. doi: 10.5787/40-3-1042

\title{
Operation Savannah: A Measure of SADF Decline, Resourcefulness and Modernisation
}

\author{
Rodney Warwick ${ }^{\bullet}$
}

\begin{abstract}
SADF conventional warfare capacity exhibited a decline during the 1950s, followed by belated efforts at rearmament and consolidation during the 1960s. However, Operation Savannah, the SADF's intervention in the Angolan civil war during 1975-1976, as the force's first involvement in a conventional-type war since 1945, exposed SADF weaknesses, but also strengths. Authorised amidst debilitating secrecy by a miscalculating South African government, Savannah demonstrated significant South African military equipment inadequacies, particularly in terms of artillery, armour and the need for an infantry combat vehicle. Savannah also gave hints of SADF strength residing in the resourcefulness of its personnel and their aptitude for mobile warfare. But rapid and effective Cuban military intervention also showed that SADF conventional warfare reaction and capacity needed urgent attention. This article attempts to address some of these themes while following the course of this "first battle" by the SADF after thirty years of relative peace.
\end{abstract}

Keywords: Operation Savannah, Border War, Task Force Zulu, SADF 1960s and 1970s

Rodney Warwick is a History teacher at the Diocesan College (Bishops) in Cape Town. During June 2009 he was awarded a PhD in Historical Studies by the University of Cape Town on the topic of "White South Africa and defence 1960-68: Militarisation, threat perceptions and counter strategies”. 


\section{Introduction}

This article's purpose is two-fold: firstly, it concerns how, during 19451975, the Union Defence Force (UDF)/South African Defence Force (SADF) ${ }^{1}$ maintained its capacity successfully to defend the country against a conventional war threat. Secondly and more pertinently, it examines Operation Savannah, South Africa's military intervention in the Angolan civil war during late 1975 to early 1976. Unlike the UDF's operations during World War Two, Savannah was a cross-border intervention to obtain political, military and foreign policy objectives in a very different context. Savannah did not involve an expeditionary force fighting afar alongside powerful allies, nor a conventional military defence of South Africa's borders. Rather it was a kind of pre-emptive military strike, shrouded in secrecy, with an intention to ensure a political objective of assisting the establishment of a post-colonial Angolan regime favourably-disposed to the South African government, and one which would also hopefully, deny future assistance to the combatants of the South West Africa People's Organisation (SWAPO).

In 1975, the global Cold War political context was dominated by the two superpowers, engaged also in their own détente process. Both still sought strategic advantages, where plausible, upon all continents including Africa. The Americans were cautious. Their military withdrawal in Vietnam had caused them a loss of international prestige and they shrank from further foreign military interventions. Soviet internal economic problems remained subordinated to ideological idealism that taught Third World anti-colonial struggles were an important site for advancing socialism. Soviet leadership perceived no conflict in principle between their improving relations with the USA while assisting developing countries, although Angola was not at the time part of Soviet planning. Reluctantly at first, then with growing conviction, ${ }^{2}$ the Soviet Union supported Cuba's independent mission to militarily aid the communist-aligned black African nationalist movement: Movimento Popular de Libertaçăo de Angola (MPLA). ${ }^{3}$ The United States responded, in the case of Angola, with hesitant undercover Central Intelligence Agency (CIA) intervention, this being one but not the only contributory factor to South African military intervention. Since the end of World War Two, South Africa's status in international relations had altered markedly, from it being a respected Commonwealth 
member to one of near pariah status in consequence to condemnation of apartheid from virtually all other countries, but particularly the Afro-Asian and socialist blocs. The USA could never allow itself to be seen in open military alliance with South Africa.

On 25 April 1974, a socialist coup in Portugal was precipitated through Metrópole citizens' political grievances, which included supporting independence for Portugal's African colonies and immediate disengagement from the attendant expensive and unpopular wars. Hasty negotiations with the three anti-colonial guerrilla movements led to the Alvor Agreement of 15 January 1975, whereby 11 November 1975 was agreed as both the Angolan independence date and for the withdrawal of all Portuguese troops. The MPLA's opposition were the Frento de Libertaçăo de Angola (FNLA) led by Holden Roberto, drawing most specifically off the Bakonga people of northern Angola. The Uniăo Nacional para a Independência Total d Angola (UNITA), with an Ovimbundu tribal base, whose leader was Jonas Savimbi, constituted the third grouping. ${ }^{4}$ By mid-1975, Angola was wracked with civil war. The original ceasefire was ignored, while across the entire country, the three anti-colonial organisations engaged one another in armed strife. With remaining Portuguese security forces confined to barracks by order of their own government, most of the white Portuguese Angolan population, witnessing if not directly experiencing the spreading anarchy, made haste in preparing to flee. ${ }^{5}$ By August 1975, the MPLA occupied and controlled most of the towns in central and southern Angola. SADF troops first entered Angola on 10 August 1975, ostensibly to protect the Ruacana hydro-electric installations at Calueque. Notwithstanding the importance of this infrastructure to SWA/Namibia's electricity and water, it seems plausible the South African government calculatingly used threats thereto as a casus belli to place their first troops.

Therefore, acting as indirect proxies for the United States and Soviet Union, South Africa and Cuba later started committing further military forces, while backing different Angolan liberation movements. Fidel Castro's decision to support the MPLA was based upon "internationism" besides no doubt raising Cuba's revolutionary status amongst the Third World. Like the SADF personnel assisting Unita and the FNLA, Cuban troops were firstly advisers/trainers/regulars, but were soon reinforced by 
significant numbers of conscripts and became involved in combat alongside their respective Angolan allies. The South African government's first priority was to stiffen the anti-MPLA forces militarily, but by late November, South African troops were pressing against MPLA/Cuban forces from Novo Redondo on the coast to the "central front," where the SADF, purportedly en route to Luanda, were attempting an advance towards Quibala. From around mid-December 1975, increasing Cuban troop numbers arrived, accompanied by significant amounts of Soviet weaponry. Further, SADF campaigning northward now required committing greater resources, with every prospect of high white SADF conscript casualties, compared to the comparatively paltry few already sustained. With SADF logistical capability strained and the South African government facing international criticism and embarrassment, after earlier denials of military involvement, all SADF personnel were withdrawn by mid-March 1976.

Savannah was prompted by South African government motives: strengthen the FNLA and Unita leaders' positions for a future political dispensation, alongside Pretoria's hope that such a "moderate" Angolan government would curb future Swapo incursions into SWA/Namibia. Prime Minister John Vorster was also pursuing his own détente foreign policy with certain black African states, and he had received clandestine appeals from some to counter growing communist influence in Angola. With the beleaguered Afrikaner nationalist government flattered by similar overtures from the CIA, direct military intervention was too tempting to resist. South Africa could facilitate an anti-colonial process making it "part of Africa", instead of being tainted as an ally of former European colonial powers. ${ }^{6}$ The vacillating Vorster was caught between his advisors, particularly the ambitious Bureau of State Security (BOSS) chief Hendrik Van den Bergh, who insisted the SADF approach intervention with extreme caution. ${ }^{7}$ The cabinet remained divided between "hawks" represented by Defence Minister P.W. Botha, who had significant support from the SADF commanders, versus “doves' epitomised by foreign minister Helgard Muller. ${ }^{8}$ This was not only because of Foreign Affairs adherence to a supposed long-held National Party government practice of non-interference in other states affairs, but also because there was no definite clarity about which political objectives direct military intervention could decisively achieve. ${ }^{9}$ Botha and the SADF commanders were adamant that they had to act to influence the 
future Angolan government, and Botha cited evidence of Soviet and Cuban military support for the MPLA, already existent by mid-1975. ${ }^{10}$

But Operation Savannah was a grave diplomatic miscalculation. South Africa would be deserted by both their fickle African allies and the CIA, while the FNLA's chances as a serious political contender were destroyed. Unita retreated to the bush to fight on for another two and a half decades. SADF senior commanders later placed personal responsibility on Van den Bergh for "misleading them" over the likely extent of American support, while Van den Bergh insisted responsibility lay with P.W. Botha. ${ }^{11}$ The South African government's secrecy constrictions were limitations with which the Cubans did not encumber themselves. SADF military intervention occurred incrementally as the situation changed, while the government's determination to prevent escalation restricted their field commanders from calling assistance from what the best SADF weaponry could offer, for example, the usage of South African Air Force (SAAF) ground attack aircraft. There was an insistence on an absolute minimum of white SADF casualties, fearing such might alienate electoral support or ferment negativity towards national service. But with conscripts involved, concealing Savannah from the white South African public was impossible, despite the initial relatively small white troop numbers using "non-South African" uniforms and equipment, a factor which further complicated logistical support. ${ }^{12}$

South African political foreign policy and military objectives were confusingly enmeshed and SADF leadership were subordinated to the government's equivocations. An exclusive committee of senior staff officers initially controlled operations according to the dictates of Vorster and Botha. ${ }^{13}$ Jannie Geldenhuys, then Army Director of Operations, commented unfavourably on this, believing the whole SADF should have been involved with the media properly informed. ${ }^{14}$ Control and command problems occurred that were directly related to the extent of secrecy. ${ }^{15}$ As late as 20 November, when SADF troops were long engaged in running fights with the MPLA/Cubans, the government was still attempted to conceal SADF involvement. ${ }^{16}$ 


\section{UDF/SADF conventional war preparedness 1945-1975}

Reorganisation: Late 1940s and 1950s

From May 1948, South African national leadership shifted from the United Party of "South Africanism" towards the republican-minded Afrikaner nationalist National Party (NP), which had been hostile to Prime Minister Field Marshal Jan Smuts's decision that South Africa participate in World War Two. Despite resultant politically originated upheavals within the 1950s Defence Force, ${ }^{17}$ the UDF was ostensibly still committed towards assisting broad Western defence interests. However, immediately after 1948, defence did not constitute an immediate priority NP issue and very few government members had acquired any particular interest or expertise thereon. New Defence Minister Frans Erasmus was no exception and his attempted "Afrikanerisation" of the UDF/SADF during the 1950s was a manifestation of NP republic preparations, besides advancing Afrikaner nationalist control and numerical preponderance within the force.

Post-war re-organisation started with the returning Special Service Brigade's (SSB) permanent force members making up the newly formed 11th Armoured Brigade, consisting of 1 SSB (Armour), 2 SSB (Infantry) and 4 Field Regiment (Artillery) with various support units, all based in Potchefstroom. Constrained by budgetary and recruitment limitations, there was an attempt to retain "all arms" training in deference to the legacy of the 1944-1945 Italian experience. The School of Artillery and Armour was established in 1946 at Potchefstroom, amalgamating the specialised and leadership training of both corps.

But efforts to "settle" the UDF into its drastically reduced peacetime organisation were complicated by political interferences, which prompted numerous experienced professional officer resignations. ${ }^{18}$ In May 1950, 11th Armoured Brigade held its first post-war exercise, where observers commented unfavourably upon its performance. ${ }^{19}$ In May 1952, the permanent force army's combat component consisted of just an infantry battalion with 100 men, with the armour and artillery components having slightly over 200 troops. The auditor general's inspection report commented that vehicles and stores were in a state of decay and disarray. ${ }^{20}$ 
During the 1950s, significant UDF rearming occurred in liaison with Britain over plans to assist in a mooted Middle East Defence Organisation (MEDO) against potential Soviet aggression. ${ }^{21}$ But MEDO was never ratified after interminable bilateral discussions, ${ }^{22}$ and Erasmus's only defence alliance "success" was the 1957 Simon's Town Agreement, with terms markedly favourable towards Britain. ${ }^{23}$ Internal political turmoil continued and a loss of skills occurred from the army and air force particularly, ${ }^{24}$ with many disgruntled English-speaking and Afrikaner war veterans departing in response to stifled promotion opportunities and politically contaminated appointments. Most of the acquired armoured vehicles $^{25}$ went directly into reserve storage. The quantities were significant, for much still remained unused by 1975, when this aging arsenal constituted the bulk of the army's armour forces reserve stock. None was ever committed into action during Savannah. ${ }^{26}$

\section{0s: Increasing South African Defence Isolation}

By 1960, Western countries generally seemed sure that Soviet penetration into Africa was not a significantly important issue; the SA government believed the contrary. ${ }^{27}$ British Prime Minister Macmillan's March 1960 "Wind of Change" speech made it clear that white South Africans could no longer count upon British support in national security, and certainly when such conflicted with African countries' hostility to apartheid. Considering the growing Afro-Asian presence in international affairs, Anglo-South African defence cooperation was being unfavourably balanced against Britain's need to achieve successful diplomacy. Therefore, outside of standing naval arrangements, the SADF's role became increasingly nebulous regarding cooperation with its traditional ally, although the British military quietly continued to value remaining links. From 1963, a United Nations mandatory arms embargo significantly closed South Africa's weapons purchases, while the SADF General Staff started emphasising "national defence".

New Defence Minister Jim Fouché (1960) attempted maintaining existing arrangements with traditional allies, while publically adopting bellicose rhetoric of "South Africa first". ${ }^{28}$ Domestically, Fouché also made some effort to restore morale in the SADF, where his predecessor's politically motivated meddling had created the well-verified impression that 
personal politics and/or an Anglo-South African identity were impediments to career advancement. NP ministers and MPs warned of a "military threat" by newly independent African states, while the SADF secretly appraised Walvis Bay as a potential target of an amphibious assault from United Nations or Afro-Asian forces. A combined arms training base was established at Walvis Bay from 1962 as a deterrent. Durban was also marked as a potential target for invasion and naval/maritime air strike. ${ }^{29}$

\section{SADF Arms Acquisitions, Training and Reorganisation during the 1960s and 1970s}

\section{The SA Navy and SA Air Force}

High 1960s defence priorities were the SA Navy (SAN) and SAAF's modernisation. At the start of the decade, approximately eighty per cent of SADF equipment was British-made, ${ }^{30}$ but arms were now purchased from France particularly, including three submarines, while three British-built President-class frigates were delivered by 1964. Final British combat aircraft orders included Canberra light bombers (1962) and Buccaneer maritime strike aircraft (1964), while the purchasing of missile armed corvettes was planned from $1971 .{ }^{31}$ By 1975 , the SAN was effectively still a small, partly modernised patrol, minesweeping and anti-submarine fleet, but its submarine flotilla provided it with limited deterrent capability against a seaborne aggressor. ${ }^{32}$ However, the SAN battled with qualified personnel shortages, while the arms embargo had created supply problems for some ammunition types, particularly shells and anti-submarine torpedoes. ${ }^{33}$

Mirage fighter orders from France extended from 1961 to 1975 and were intended to upgrade the SAAF's fighter interceptor capability significantly. ${ }^{34}$ Over these years, the SAAF acquired 26 different aircraft types, indicative of how it had actually been neglected in the 1950 s. $^{35}$ While the essential corresponding radar network for the Mirages was not finally completed until the mid-1970s, ${ }^{36}$ the Cactus surface to air missile system was operational by 1971 . Flawed as it was in certain respects, this SAAF modernisation boost ensured there existed, for a period, some effective air interception capability, appropriate to managing any conceivable threat from an African context, along with an enhanced ground attack capability. But the SAAF's upgrade also did not include aircraft 
numbers conducive to it being able to sustain conventional war operations over a lengthy time. ${ }^{37}$ Another significant SAAF development was the upgrading from 1973 of 85 Advanced Flying School at Pietersburg, in anticipation that fighter aircraft and honed combat/flying skills would in time be required for the Border War. ${ }^{38}$ During the early 1970s, the SAAF however utilised the most basic of infrastructure in the northern parts of Namibia. ${ }^{39}$

By 1975, the SAAF possessed some limited air-lift capacity through its acquisition in 1963 and 1969 of 7 C130 and 9 C160 aircraft respectively, joining the small Dakota fleet. These along with French-built Alouette, Super Frelon and Puma helicopters were indispensable to Savannah's logistical needs. ${ }^{40}$ Amongst SAAF personnel there were light aircraft and helicopter crews with operational exposure to counter-insurgency, resulting from their limited and secret support given to both Rhodesian and Portuguese security forces since 1967 (Rhodesia) and 1968 (Angola). ${ }^{41}$

\section{The SA Army}

Training: Early 1950s to 1970s - Infantry and Special Forces

From 1952, three continuous months' balloting started for compulsory military service amongst white school leavers. Only a very limited required number of recruits were accepted. From 1962, the SADF's manpower quantity increased as more trainees were balloted for the now 9 months' continuous service. Under Commandant General Rudolf Hiemstra's initiative, compulsory conscription began in 1968 for all white males during their eighteenth year. The army was assigned the greater proportion, and the larger grouping herein was despatched to infantry, for which new training camps were established. ${ }^{42}$ The army struggled during this period with inadequate facilities, poor junior instructor quality and low permanent force recruiting numbers. ${ }^{43}$ Uncertainties existed as to how much conventional warfare preparedness had to be stressed compared to counter-insurgency training. Leopold Scholtz believes that, despite some significant small arms upgrades, the 1960s infantry battalions received a poor level of training. ${ }^{44}$ An exception being 1 Parachute Battalion, founded in 1961, with an original intention of providing the army with a rapid deployable unit against internal insurrection. 
The army possessed over two hundred Saracen armoured personnel carriers, but integrated these only on a very limited basis into infantry and armour units, besides a few citizen force regiments. ${ }^{45}$ Conscripts were exposed to minimal conventional war doctrine training combining all combat arms, although the battalion group operational from 1962 at Walvis Bay was an exception. In 1972, continuous national service was increased to twelve months and by 1974, there were 10 full-time motorised infantry battalions, besides the parachute battalion. ${ }^{46}$ The infantry reserve comprised 42 citizen force infantry battalions, a parachute regiment and over 200 commando units dedicated to internal defence. Plans were in place to establish volunteer black infantry units along ethnic lines, comparable to the coloured Cape Corps battalion, reactivated during the early 1960s. ${ }^{47}$

In 1975, a very small core of SADF Special Forces members and paratrooper regulars possessed some combat experience. Individual paratroopers had in August 1966 assisted the SA Police in attacking the Swapo base at Ongulumbashi, Namibia, ${ }^{48}$ while during the late 1960s/early 1970s, other personnel were exposed to clandestine placements in Rhodesia and the Portuguese colonies, and with Biafran secessionist forces during the Nigerian civil war. ${ }^{49}$ A small prototype Special Forces component had also trained with the Rhodesian SAS in 1967. ${ }^{50}$ From around mid-1970, this unofficial Special Forces grouping, led by Jan Breytenbach, formed the basis of 1 Reconnaissance Commando being formally established in October 1972. ${ }^{51}$ Members of 1 Reconnaissance Commando and 1 Parachute Battalion gained further counter-insurgency practice during 1974, when operating in south-eastern Angola, ${ }^{52}$ while a few other SADF members from other army corps also gained experience in counter-insurgency actions through clandestine placements amongst Rhodesian forces. ${ }^{53}$

Armour: 1960s to early 1970s

Observing the collapse of MEDO, the South African government in September 1960 sold half the army's Centurion tanks. But compared with armour developments globally, the remaining Centurions were in the process of becoming obsolete. ${ }^{54}$ The School of Armour in Bloemfontein had been established during 1966 for leader training, ${ }^{55}$ while the SSB continued to receive conscripts. ${ }^{56}$ French Panhard AML-60 and 90 armoured cars were acquired from 1961, while further additions were 
intended to be locally produced ${ }^{57}$ as the Eland 60 and 90 . As early as 1969 , there had been discussion amongst armour officers for the Eland's replacement; ${ }^{58}$ the Eland 90 s were not originally envisaged by the SADF as tank substitutes, but as scout cars for urban/road/border/rural area patrolling. ${ }^{59}$ By 1975, both Eland variations were the main SAAC armour vehicles, having undergone additional modifications during the early 1970s, ${ }^{60}$ with 369 Eland-60s and 131 Eland 90s available (in 1970). Conventional warfare planning meant the addition of a further 356 Elands, ${ }^{61}$ while an anti-tank missile capacity was provided by French Entac, acquired in $1969 ;{ }^{62}$ this missile equipment being used to a limited extent during Savannah.

Artillery: 1960s to early 1970s

From 1964, the Artillery School in Potchefstroom was this corps' leader training institution, while 4 Field Regiment served as the conscript training unit. Medium/field artillery was not included during 1950s and 1960s arms purchases, although deficiencies were noted from 1968, but only formalised in 1973, when the army's envisaged conventional restructure pre-supposed upgraded artillery. ${ }^{63}$ By Western (and Israeli ${ }^{64}$ ) standards, the conventional large artillery calibre of the early 1970s was $155 \mathrm{~mm},{ }^{65}$ but with no progress in new acquisitions, the SADF continued with its World War Two era British equipment. National servicemen of 4 and 14 Field Regiments ${ }^{66}$ were therefore trained with the $88-\mathrm{mm}$ ( 25 pounder) and 140-mm (5.5-inch) guns, towed by Bedford and Magirus Deutz gun tractors of 1950s and 1960s designs. Obsolete 88-mm Sexton self-propelled artillery was also on the inventory. ${ }^{67}$ Artillery upgrade was only in the initial investigation stage when the Savannah deployment occurred, ${ }^{68}$ but overall, existing gun numbers were lacking ${ }^{69}$ while artillery requirements went beyond gun acquisitions, but also included associated equipment. ${ }^{70}$ Target acquisition/locating equipment dated from the 1950s, of which mortar locating radar was the most useful. ${ }^{71}$ The Green Archer system which originated from $1962^{72}$ was not used in Savannah; instead, the artillery employed their more modern Cymbeline radar ${ }^{73}$ although its reliability proved questionable in the heat and wet. $^{74}$ Anti-aircraft artillery acquisitions during the 1960s included 35-mm Oelikon guns, but during Savannah, only 20 -mm anti-aircraft guns were deployed and with very limited success against MPLA/Cuban aerial reconnaissance. 


\section{Conventional Warfare Organisation: 1960s}

SADF conventional warfare planning altered several times during the seven year period of Commandant General (CG) Rudolf Hiemstra being either the SADF Chief (1965-1972), or previous CG Piet Grobbelaar's deputy (19601965). ${ }^{75}$ For most of the 1960s, SADF strategy reflected a "combat group" concept, grounded upon organisation against possible black insurrection. From 1962, training bases were widely spread and included "full time force components". ${ }^{76}$ Hiemstra also initiated abolition of the Defence Secretariat, reasoning that it complicated communications between the SADF's top structure and the responsible minister. Hiemstra's concept of a "joint combat forces" (JCF) commander and "joint maritime forces" commander, instituted late in 1965, was abandoned shortly after he had retired by 1972 . These were structures by which any threat could supposedly be countered, with the two "chiefs" selecting their required forces, while also comprising the SADF's "supreme command," along with the CG and three services heads. ${ }^{77}$ In February 1970, the magazine Personality ${ }^{78}$ introduced Hiemstra and the SADFs most senior generals and admirals in an article clearly intended to reassure white South Africans on defence issues. Readers (or national servicemen parents) were told that military service was of national importance and their "boys" well looked after, with taxes responsibly spent upon increasing but necessary defence budgets. Hiemstra emphasised the need "to maintain a well-trained, well-equipped and balanced force, capable of fulfilling whatever demands may be made on it ..." Ironically, such change only started moving slowly forward from 1974. In 1970, when Army Chief Lt. Gen. Willem Louw laid out his plan for enlarging the army, ${ }^{79}$ JCF Commander General Alan ("Pops") Fraser had already in June 1968 remarked, that the envisaged division "was a 'paper tiger' on account of the deficiency of vehicles, weapons, ammunition and a headquarters". This was a candid acknowledgement that the 1960s had not been markedly successful for planning an effective conventional force.

Unfortunately, Hiemstra throughout his career had prioritised continued politicisation of the SADF, above studying and managing its appropriate reorganisation and modernisation. ${ }^{80}$ Malan wrote that very early during his appointment as Army Chief in 1974, he established that no priority list existed for the acquisition of armaments, or any clearly formulated requirements with regard to existing armaments. Consequently, 
armaments had been purchased haphazardly; indeed a critical reflection upon his predecessors. ${ }^{81}$ During the 1960s, the increased value of special forces was being emphasised; yet, in 1968, Hiemstra saw no value in creating such an SADF unit. Lt. Gen. Louw and intelligence chief Maj. Gen. Fritz Loots, supported by P.W. Botha, gave their assent to the creation of such a unit, supposedly without Hiemstra's knowledge. ${ }^{82}$

Hiemstra was due to retire in 1973, but left a year earlier, when offered by Botha (quoting Hiemstra), "another position where for a few years I can still perform useful work for our country" ${ }^{\text {33 }}$. But his discarded combat structure was indicative of his diversions from the SADF's real priorities. Such were being determined elsewhere by changing doctrinal patterns. Savannah veteran George Kruys explained that already by 1969, some discussions at the Army College centred on any future potential conventional attack being landward, not seaborne and that mobile warfare needed emphasis. ${ }^{84}$ But during the 1960s/early 1970s, the SADF's doctrinal understanding still emphasised static defence. For example, the early 1960s top-secret plan Operation Olympus, intended to defend Walvis Bay, was a typical World War Two-type defensive pattern. ${ }^{85}$ SADF World War Two veterans remained prominent during the 1960s, not least in the Staff College and combat corps. ${ }^{86}$ And while not suggesting they formed a bloc deliberately opposing modernisation, it is comprehensible that after MEDO's collapse, SADF top commanders could not with conscious urgency anticipate South Africa facing any looming conventional threat.

Compared to World War Two, counter-insurgency threats must have appeared small beer; the notion of training towards a mobile warfare doctrine still had to permeate. ${ }^{87}$ The counter-insurgency warfare "school," still in the ascendant during the immediate pre-Savannah years, was unconvinced by Israeli victories in three quick conventional wars, being attributable to well-commanded, highly manoeuvrable and well-supported ground and airborne army formations. ${ }^{88}$ After a training course held in 1968, which dealt with counter-insurgency threats against South Africa, including the danger of such transforming into a conventional assault, a decision was apparently made that the army would not be bound by static defence, but would start developing towards mobile warfare. ${ }^{89}$ However, during the same year, Fraser introduced his landmark work Lessons learnt from past revolutionary wars, ${ }^{90}$ resulting in the emphasis remaining on 
counter-insurgency warfare ${ }^{91}$ - a miscalculation, for it implied the SADF would not need to train for a future conventional war.

\section{Conventional Warfare Structure: 1974-1975}

By 1974, the army's structure had started to become more settled and its two roles clearly defined: an effective conventional force but also capable of training and maintaining a counter-insurgency capacity. By then, $7^{\text {th }}$ Infantry Division and an $8^{\text {th }}$ Armoured Division had been established, each with three brigades, together constituting 1 SA Corps. This reorganisation was also intended to avoid “doctrinal pollution,” whereby reservists particularly, because of their limited training time, were unable to adequately assimilate two markedly different concepts of war. ${ }^{92}$ The intention was for the brigades to begin training at the start of $1975 .^{93}$

From late 1975, newly appointed SADF Chief Admiral Hugo Biermann, established a new top management structure consisting of himself, the three new services heads and directors of intelligence and operations. $^{94}$ The SADF had taken over patrolling the SWA/Namibian border from the SA Police, whose resources were inadequate, notwithstanding serious inter-service conflicts, including resentments that the police had long usurped the SADF's role. ${ }^{95}$ The SADF were now principally concerned with counter-insurgency operations against Swapo and anti-guerrilla warfare; therefore, receiving priority emphasis during conscript training. ${ }^{96}$

\section{Operation Savannah}

Savannah was not the first time South African armed forces had deployed deep into Africa, and by 1975, the SADF had technologically overcome at least some of the logistical challenges envisaged by Maj. Gen. Jack Collyer, when he wrote his histories intended for prompting staff officer thinking, when planning for war in Africa. ${ }^{97}$ The UDF's First World War African campaigns and Second World War involvement in North and in East Africa, ${ }^{98}$ also demonstrated some South African military "knack" of offensive innovative mobility; distant strands of this still connected during Savannah. ${ }^{99}$ 
Only a small part of the SADF's capacity was mobilised for Savannah, an operation which did not resemble the standard defensive conventional war scenarios the SADF was orientated towards - particularly if we define land conventional war as a situation where heavy weapons (specifically armour and artillery) are involved, with supporting troop numbers at divisional and brigade strength, against similar counterparts, with combat air support on both sides. Forces during Savannah were smaller formations with some artillery and light armour support and often deployed as motorised columns. Air operations involved extensive logistical support, along with light aircraft and helicopter reconnaissance missions. The only combat air operations were one or two inconsequential attacks upon SADF forces and one ineffective SAAF bombing attempt.

The original SADF aim was to support Unita and the FNLA with arms and training, using comparatively few white soldiers or heavy arms. Task Force Zulu's initial advances were entirely dependent upon SADF leadership and armoured cars. Recognisable conventional war situations occurred during Zulu's final thrusts through Novo Redondo, the Ebo battle, the artillery duels, the SADF advance around/over Bridge 14, Battle Group Orange's operations and Battle Group X-Ray's advances during December 1975, attempting to gain control of the Benguela railway line.

\section{Initial Direct Intervention: SADF/UNITA}

An SAN submarine was on occasion present off Angola from August $1975,{ }^{100}$ while two frigates alternated in patrolling the coastline. ${ }^{101}$ The South African government first involved army units from 9 August to protect the Ruacana and Calueque dam/hydro-electric infrastructure and by 20 October, these 2 SAI troops, with armour support, ${ }^{102}$ advanced upon Rocades where the attached Elands and mortars accompanied Col. Koos van Heerden's Task Force Zulu on its forays through southern Angola and up the coast. The secrecy extent was such that Zulu's commanders and Comdt. Boy du Toit of 2 SAI were not even aware of their intention to co-operate in driving the MPLA out of Rocades. ${ }^{103}$

In late August, the South African government responded to secret CIA and African requests, by consenting to extend military training for antiMPLA forces. UNITA already had SADF instructors and weapons under 
Comdt. Eddie Webb at Colombo (near Silva Porta) ${ }^{104}$ while FNLA dissidents were trained by Comdt. Jan Breytenbach's team at M'pupu, close to the SWA/Namibian border. ${ }^{105}$ By mid-September, the MPLA, assisted by the Cubans, controlled most towns between Namibia and Luanda, while Holden Roberto's FNLA in the north was no dire threat to Neto's base in the capital. Serious fighting began when the SADF instructors with Unita received news of MPLA forces converging upon Novo Lisboa. The South Africans responded by manning five old Panhard armoured cars and three Entac anti-tank missile vehicles and advanced accompanied by several hundred Unita infantry. This "SADF" force was ambushed ten kilometres south of Norton de Matros, but fought back causing significant casualties against a handful of Unita losses. ${ }^{106}$ It was an important engagement for it damaged MPLA confidence at an early stage. ${ }^{107}$ But as Gleijeses points out, citing Spies's work, the battle also showed that Unita could not survive without SADF help and the South African government faced a choice, between either a MPLA victory, or pursuing further SADF intervention. ${ }^{108}$ By 22 October, a squadron of SADF-crewed Elands was flown to Silva Porta where it joined the newly established Battle Group Foxtrot. ${ }^{109}$

\section{Savannah Rolls in Earnest}

Task Force Zulu advanced from SWA/Namibia as two combat groups, Alpha and Bravo, with Bushman/Flecha ${ }^{110} /$ FNLA troops transported in commandeered vegetable trucks, with an SADF leadership and heavy weapon operator core. ${ }^{111}$ Malan's orders included that military intervention was also intended to assist Vorster's African détente policy, ${ }^{112}$ but no brief existed to advance on Luanda, a point disputed elsewhere. ${ }^{113}$ Following Spies, Heitman states the intervention was limited to involve a maximum of 2500 men and 600 vehicles. ${ }^{114}$

The basic objective was that by the 11 November, Independence Day, SADF assistance would have rendered Unita and the FNLA strong enough to retain what territory they held, possibly even preventing an MPLA political victory. The MPLA were to be ejected from southern Angola and control established over the Benguela railway line. Foxbat was intended to block any western MPLA advance ${ }^{115}$ and in late October, the SADF battle group clashed again with advancing MPLA forces, halting them and inflicting casualties which included a Cuban brigadier. ${ }^{116}$ Near Luimbale, 
three MPLA armoured vehicles were destroyed and the rest of this force forced to retreat. Foxbat then assisted Zulu during fighting at Cabul, and after heavy fighting at Norton de Matos on 3 November, moved up to the central front by 11 November, taking positions around Cela and Santa Comba. ${ }^{117}$

\section{Task Force Zulu's Dash Up the Coast}

Van Heerden was instructed to advance as far north as possible before 11 November, with an emphasis upon securing the ports. Starting on 13 October, after the capture of Pereira D'Eca, Zulu advanced to Rocades. At Sa da Bandeira (21 October), the MPLA strengthening its defences, ${ }^{118}$ but were swept aside again, while two additional FNLA companies were attached, together with more armoured cars and mortars. ${ }^{119}$ After Sa da Bandeira's fall, two 1 Parachute Battalion companies arrived and were split up as headquarters guards, besides distribution amongst all battle groups. ${ }^{120}$ Once Mocamedes was secured on 28 October, confidence surged amongst Zulu's leadership. ${ }^{121}$ Catengue (31 October) involved a significant Cuban presence, evident not only amongst their casualties, but in the improved defence construction. ${ }^{122}$ At Cabul, an MPLA force from Novo Lisboa was destroyed by Zulu in collaboration with Foxbat. Benguela was seized by 5 November, while the heaviest fighting occurred just before Novo Redondo was reached. ${ }^{123}$ Although by this stage, Cuban special forces had arrived ${ }^{124}$ and had stiffened the demoralised MPLA.

Under Comdt. Delville Linford, Alpha led Zulu towards Novo Redondo, where at the Quicombo River, $19 \mathrm{~km}$ short of the town, an Eland troop was ambushed, and Linford withdrew after taking significant casualties amongst a conscript-crewed mortar group. ${ }^{125}$ However, the same MPLA/Cubans were later beaten back, with support from a recently arrived 88-mm artillery troop. After further fighting, Novo Redondo fell in SADF hands by 13 November. Zulu's intention was now to advance to Quibala via Porto Amboim and Gabela. Cuban expertise ensured the bridge over the Queve River was destroyed, besides all others on the designated route. An attempted probe of the defences by Breytenbach's Bravo group was forced to retreat after coming under intense rocket and mortar fire. Although later, the 88-mm guns again assisted destroying three MPLA/Cuban rocket positions. ${ }^{126}$ After that, hostilities on this front became limited to artillery 
duels, ${ }^{127}$ besides an attempt on 24 November to investigate damage at the bridge on the Gabela route, leading to casualties when an Eland was immobilised by MPLA mortar fire. ${ }^{128}$ By 18 November, Task Force Zulu had travelled 3159 kilometres, during which an impressive tally of engagements occurred, with severe casualties inflicted upon the MPLA/Cuban forces for minimal SADF losses. ${ }^{129}$ Until halted by rivers which could not be forded without combat engineering equipment, Zulu's successes could be attributed to the SADF leadership group and their heavy weapons capability, particularly the Elands manned by well-trained conscripts. ${ }^{130}$ Zulu was also sufficiently supplied by air transportation and overall better organised and equipped than their MPLA opponents. ${ }^{131}$

\section{Cuban Reinforcements/FNLA Defeat in Northern Angola}

By 7 November, Castro had decided to reinforce the original Cuban instructors via Operation Carlota, starting with an air-lifted 652-man special forces battalion, followed by an artillery regiment. Political power was formally handed over by the Portuguese governor on 11 November, leaving the MPLA as the government in Luanda, recognised by a number of socialist and African states, but nothing similar was forthcoming for the makeshift FNLA/Unita government at Huambo (Novo Lisboa). Yet, with their forces in the south defeated, the MPLA faced a serious problem; further SADF/Unita/FNLA advance could threaten water, power and food to Luanda. ${ }^{132}$

But now events in northern Angola were to have a profound impact upon Savannah. On 10 November, Holden Roberto's FNLA troops, supported by 120 Portuguese Angolans, two Zairian battalions, a handful of Panhard armoured cars and two North Korean-built 130-mm cannons, in preparation for an attack upon the capital, launched a suicidal assault upon Quifangondo, $50 \mathrm{~km}$ east of Luanda. Generals Malan and Viljoen had visited Ambriz on 4 November and found Roberto, against all advice, persisting with this plan. Two days earlier, Cuban special force members had arrived and immediately went to assist MPLA defences, joining other Cubans manning 6 BDM-21 rocket launchers. ${ }^{133}$ Botha and the SADF generals continued assisting Roberto and even acceded to his request for artillery (three 140-mm guns and crews), besides support via three SAAF Canberra light bombers. The FNLA attack was a predictable disaster, 
observed by the SADF advisory team under Brigadier Ben Roos together with CIA officers. The BDMs outranged the SADF artillery, and the aerial bombing (for fear of SAAF casualties) occurred from too high, being therefore completely ineffective. Further useful CIA assistance ended and all remaining SADF personnel were evacuated by the SAN from Ambriz on 27 November, while by mid-February 1976, the remaining northern FNLA troops were completely routed.

\section{Battles of Ebo and Bridge 14: The "Stalled" Central Front}

On 12 November, Savannah's command structure was formalised: 101 Task Force was established under Maj. Gen. Andre Van Deventer with its headquarters at Rundu, although the South African government had already decided upon a gradual withdrawal from Angola. After leaving Alpha at Novo Redondo, Zulu swung east and when arriving at Cela, Breytenbach noted the war now looked more a reflection of typical SADF white racial demographics. ${ }^{134}$ But while Cuban reinforcements continued arriving, the SADF was operating at increasingly longer logistical lines, and Van Deventer was concerned that the SADF's logistics would struggle to sustain any war escalation. ${ }^{135}$

Meanwhile "a few hundred" Cubans commanded by Diaz Arguelles and about 400 MPLA troops, shadowed the SADF east across the $160-\mathrm{km}$ front, assessing which routes they were likely to take in advancing upon Quibala. ${ }^{136}$ The SADF had recaptured virtually all the territory in the south lost by Unita and the FNLA during previous months, but a possible MPLA defeat had already been averted by the FNLA defeat outside Luanda. During one SADF pursuit of MPLA forces, the main bridge (later Bridge 14) was blown, destroying the most obvious Quibala approach. Several other clashes occurred with Cuban/MPLA forces in the Ebo/Hengo area, particularly on 18 November near a junction called the "Y", where Foxbat's troops got the upper hand. ${ }^{137}$ By 22 November, a tactical headquarters under Brig. Dawie Schoeman was established in Cela, controlling all combat groups in 2 Military Area. Responding to orders based upon political imperatives, Schoeman instructed Comdt. George Kruys, the newly appointed Foxbat commander, to advance in haste towards Quibala. The approach route was a well-watered agricultural district, where numerous 
winding roads joined farms, although these were often impassable during the rainy season.

The South Africans had been reinforced by three more companies of Unita and FNLA infantry, but the actual probe through Ebo was undertaken by a team consisted of four 88-mm guns, two FNLA and two Unita companies, an Eland squadron, two Jeep-mounted 106-mm recoilless guns and two 4.2-inch mortars, with observation support from a light aircraft. Kruys feared any surprise had been squandered earlier on 22 November, after an unknown aircraft overflew SADF positions and no attempt was made to destroy it. Advancing in swampy territory, the vehicles were compelled to keep to the road. The force's commander, Capt. Johan Holm, led the column into an area well reconnoitred for ambush. A group of 70 Cuban special force troops were concealed on the northern bank of the Mabassa River bridge, ${ }^{138}$ armed with RPG launchers and recoilless guns and supported from their rear by BDM-21s and mortars. During the ensuing engagement, several Elands were either destroyed or bogged down ${ }^{139}$ while, because of aircraft sighting problems, the SADF artillery battled to locate targets effectively. ${ }^{140}$

Kruys later lamented that ill-trained Unita infantry had to be used to support the advance, resulting in their headlong flight from the Cuban/MPLA bombardment. He also cited the orders to force through Ebo as markedly unsound, ${ }^{141}$ particularly because information received prior, indicated the route was rugged, with many potential delaying positions. The Cuban's success was celebrated by them as the most decisive military moment in the war. Arguelles, who was killed a few days later, was memorialised by the Angolans. ${ }^{142}$ The battle damaged the "invincible image" of the South Africans and their Eland 90 armoured cars and SADF reinforcements were urgently requested to hold the line and counter the skilled Cuban artillery. ${ }^{143}$ A lull for several days allowed the Cubans space to further build up their forces from resources now landing at Luanda. ${ }^{144}$

SADF white troop losses at Ebo included 5 killed and 11 wounded, while an estimated 50-80 Unita and FNLA infantry perished with approximately the same number wounded. ${ }^{145}$ Trained SADF infantry were sought to overcome natural ambushes/obstacles, while additional SADF artillery was about to be deployed and SADF infantry were now considered 
necessary for gun protection and observation posts. One company of 2 SAI infantry arrived at the central front intended also to be used in an offensive role, if required. ${ }^{146}$ Other reinforcements amounted to 254 men and 49 vehicles dispatched by road. An artillery component under Comdt. Joffel van der Westhuizen arrived at Cela on 29 November, while one troop each of armoured cars and 140-mm guns was sent to Novo Redondo to support Battle-group Alpha while another replacement artillery troop joining Foxbat. Therefore, by the first week of December, Swart had 723 SADF soldiers, including a full artillery regiment, 4 companies of Unita infantry and eleven Eland troops. ${ }^{147}$

On 1 December, Admiral Biermann gave the South African press an "off the record" account, acknowledging the virtual collapse of the FNLA as a fighting force and that SADF troops were now $700 \mathrm{~km}$ into Angola, where most of their casualties had occurred. He stated further that the MPLA had the largest and best force amongst the liberation movements and was likely to win any long-term civil war. No mention was made of Cuban forces, although for several months, newspapers had skirted the restrictions of the Defence Act, reporting on the civil war and alluding to the presence of white troops on both sides. ${ }^{148}$ Only from January 1976, did Paratus start producing some sanitised articles on Savannah, commencing with a report about troops guarding the Ruacana and Calueque water installations. ${ }^{149}$

During the "Bridge 14" victory in mid-December, outstanding SADF artillery deployment proved decisive, particularly the 140-mm guns which cost Cuban/MPLA forces heavily in both men and equipment. After SADF engineers had repaired the bridge with logs, advancing was militarily the most obvious thing to do, but the makeshift crossing could not support the guns, while rain and mud hampered the Elands return. But Cuban/MPLA casualties were severe, with losses of a magnitude which the SADF never suffered during Savannah. ${ }^{150}$ Yet, despite their hard defeat, the Cuban/MPLA forces were not completely destroyed, for they regrouped and continued to block the Quibala/Luanda route. ${ }^{151}$ Malan visited the front on 15 December and reiterated that the SADF would withdraw in January and no further reinforcements were to be dispatched, but aggressive use was to continue with existing resources. ${ }^{152}$ The battle line was now effectively static, extending across scattered positions from the west (Novo Redondo) to the east where Battle-group Orange was deployed and in regular action. 
On 18 December, the SADF forces near Quibala suffered a severe propaganda defeat, when four white troops were captured while recovering damaged vehicles, providing conclusive proof that South Africans were fighting in Angola. By 20 December, much of Foxbat's personnel were relieved by fresh troops: Brig. J.D. Potgieter replaced Schoeman and Comdt. Pat Venter took over from Kruys. ${ }^{153}$ The 2 SAI troops were replaced by two companies from $5 \mathrm{SAI}$ and 8 SAI respectively, along with two troops of armoured cars from reserve Battle-group Beaver; making up now over 3000 SADF troops in Angola, above the original ceiling laid down by the government.

Battle-group Orange, formed originally as a reserve in late November, had been shifted to the central front to locate potential river crossings east of Bridge 14, starting with the Salazar Bridge, hopefully thereafter, forcing a route through to Quibala. Unfortunately, this crossing had been destroyed

while the Pombuigi River to the west was equally impassable. ${ }^{154}$ The SADF's inability to forge this river was a serious setback for the general planning. By 20 December, Battle-group Orange's position came under increasing Cuban/MPLA bombardment, while enemy patrols had infiltrated behind the South African artillery, placing the gunners under particular strain. The Cubans had excellent observation of Orange's positions and on 23 December, an artillery duel resulted in two SADF gunners killed. On Christmas Day, South African patrols sent to Orange's rear were strafed by an enemy jet fighter, while the 140-mm range limitations ensured they could not silence the BDM-21s. ${ }^{155}$ Despite the South Africans still inflicting casualties on their opponents, Orange encountered increasingly strong resistance which at times threatened to envelope them, and by early January 1976, this front looked the most precarious of all the SADF positions. Similarly Battle-group X-Ray, after capturing Luso on the Benguela railway line, could not force their control over the rest of this infrastructure running east to Zaire.

\section{Citizen Force mobilisation}

Vorster and P.W. Botha were the prime movers behind the decision in either late December or early January, for all SADF forces to be withdrawn from Angola. ${ }^{156}$ Cuban troops with Soviet weaponry continued to pour in, bolstering Cuban/MPLA confidence and aggression. It was very obvious 
that, if the SADF intended to continue contesting Angola, they would require very significant and politically untenable reinforcements; indeed, already the SADF's deployed conscript service was extended for an extra month, while 5000 citizen force members were mobilised to cover the withdrawal. After 8 January 1976, these reservists started relieving the national servicemen, who departed alongside thousands of fleeing Portuguese civilian refugees. On 3 February 1976, P.W. Botha told the Washington Post there were $3000-4000$ South Africa troops in southern Angola, across the border at maximum fifty miles north of the Namibian border. ${ }^{157}$ Meanwhile the Cubans/MPLA continued advancing slowly south, concerned with their now lengthening logistical lines and hampered by SADF mines and damaged bridges. But the Cuban military did not draw the South Africans into any further battles, despite Castro's bluster on 15 March from Conakry in Guinea, threatening to attack and even extend the war into Namibia. When President Neto gave assurances that the Cunene dams would not be interfered with, the SADF brought all its troops out of Angola by 27 March. The retreat brought mixed receptions in the Republic: the NP-supporting Afrikaans press spoke about intervention being a "ligte mistakie", ${ }^{158}$ while a retired SAAF Brigadier J.G. Willers referred in a press letter to it being South Africa's "Bay of Pigs". ${ }^{159}$

\section{SADF “lessons” from Savannah and Modernisation}

The most important of these lessons concerned army equipment deficiencies, ${ }^{160}$ specifically inadequate armour and artillery. But only a thorough archival examination will provide a detailed assessment of the degree to which the SADF acknowledged and responded to all issues, particularly sensitive matters such as how the operation was commanded, morale of troops and the care of wounded. ${ }^{161}$ Jannie Geldenhuys who was in charge of the army's debriefing conferences, refers to substantial changes/adjustments occurring regarding battle techniques/procedures, equipment and closer cooperation between different army corps and the three services. ${ }^{162}$

\section{Armour}

Eland armoured cars crewed mostly by national servicemen formed the column spearheads, although these vehicles were originally intended only to 
support motorised infantry while operating on good roads. The operational reality demanded far more, but being an armoured car and not a tank, the Eland combat capability was restricted when driving upon terrain more suited for tracked vehicles. ${ }^{163}$ Its limitations on very rough roads was noted when Foxbat on 30 October 1975 proceeded with 13 Elands up the exceptionally difficult Benguela route to Babaera. Upon their arrival, only seven cars were still in proper working condition. However, despite its limitations, the Eland 90s lifted the confidence and morale of the infantry. ${ }^{164}$

Other criticisms of the Eland included its limited capacity to store ammunition - just 20 rounds $90 \mathrm{~mm}$, while armour logistical support was often found wanting. The lowness of the vehicle made sighting difficult over the thick Angolan bush, which differed from terrain on which crews had trained in Republic bases or at Walvis Bay. ${ }^{165}$ But at the height of the central front fighting, the Cuban/MPLA forces had no armoured vehicle matching the Eland, let alone the numbers available to SADF commanders, most particularly when the SADF advanced over the repaired Bridge 14, using their Elands devastatingly against the retreating Cuban/MPLA troops. Soviet-designed BDRM scout cars, being thinly armoured with just a heavy machine gun bore no comparison, while MPLA/Cuban forces had limited numbers of PT-76 amphibious light tanks, but these were also too lightly protected. Armoured cars were not part of Soviet conventional warfare doctrine, as imitated by the Cubans.

The Elands provided the SADF with mobility and fire power that could be used aggressively. But although resistant to small arms and shell shrapnel, Elands were vulnerable to Soviet RPG-7s and recoilless guns, while anti-tank defence was a Cubans specialty. Elands rarely encountered tanks during Savannah. One exception occurred on 18 December, when Battle-group Orange deployed some $50 \mathrm{~km}$ north east of Foxbat, engaged T34 tanks across the blown bridge over the Pombuigi River. Eland 90-mm fire disabled one tank and caused the other to retreat. ${ }^{166}$ However, also on this critical front, five Elands were rendered unserviceable through mechanical failure. ${ }^{167}$ Any future infantry fighting vehicle needed to be capable of operating for extended periods independently of logistical backup. The Eland's limitations and the infantry's mechanisation requirements stressed the urgent need to accelerate Ratel infantry fighting vehicle (IFV) developments, already existent from 1974. Ultimately, the 
SADF were provided with a versatile six-wheeled vehicle that could also deliver 90 -mm fire power and deploy troops, with several variations thereof regarding main armament. ${ }^{168}$ The initial post-Savannah requirement was $504 .{ }^{169}$

\section{Artillery}

During Savannah, SADF artillery was hindered by a "strategic ability deficit", namely the prompt shifting of guns and related equipment from bases/storage in the Republic to the Angolan battle zones. Secondly, tactical mobility (physical man-handling around) of guns was hindered by the Angolan rainy season with compounding difficult bush and muddy terrain. The Cuban/FAPLA artillery, Soviet $130-\mathrm{mm}$ and $122-\mathrm{mm}$ guns, and not least 122-mm BDM-21 launchers, held a very clear range advantage and therefore, SADF artillery ingenuity had to compensate. Van der Westhuizen explained that it was during the Bridge 14 artillery duels that the SA Artillery departed from much of its Royal Artillery-inherited culture. SADF artillery learnt to fight "independently and aggressively" and not only in a predictable pattern as fire support for infantry and armour. Guns were at times deployed well forward, fired, and then moved back before Cubans/FAPLA could retaliate - "guerrilla tactics with a gun". The 140mm shells' comparative limited explosive power was another prompt to push guns ahead, ensuring each shot counted. ${ }^{170}$

However, forward deployment of artillery often placed crews close to the direct fire zones, ${ }^{171}$ but the intense, saturating fire supporting the Bridge 14 attack, ensured sustained advance by Foxbat's armoured cars and infantry. SADF artillery also lacked a high angle capability, meaning that the higher the angle elevation a gun fires from, the more it can be concealed and protected behind high ground. ${ }^{172}$ But what the artillery did achieve during Savannah ensured their upgrading needs received priority attention thereafter. ${ }^{173}$

Although the SADF artillery was outranged during Savannah, Wilsworth comments:

Range is not the only factor to consider in the analysis of artillery. Factors such as command and control, tactics and battle-handling (doctrine) also play a major part, not to mention ammunition flexibility. So, whilst we were 
outranged we weren't outgunned. The Soviet employment of artillery was very rigid and command and control was centralised - no room for lateral thinking or innovation. We were the opposite. ${ }^{174}$

To fight effectively, gunners must possess all their requisite equipment in the combat zone. Future planning is needed to accommodate a scenario whereby guns might again be urgently required to deploy. The artillery reinforcements brought to the central front from 25 November, travelled $2500 \mathrm{~km}$ by rail and road from Potchefstroom. One immediate solution was the placing at Grootfontein of a full 140-mm battery, along with reserves, while the post-Savannah gunners' debriefing stressed the need to acquire new longer-range guns. ${ }^{175}$ Three essential features for future artillery were that $155 \mathrm{~mm}$ was the correct calibre, not only powerful as an explosive conventional warfare round, but also appropriate for nuclear, biological or chemical weapon use. The Cuban/MPLA forces during any possible future conflict would again use Soviet artillery doctrine, which utilised massed bombardment. Therefore, the side with the best advantage would be that with artillery equipment capable of superior tactical mobility.

Because of the hostile international climate towards South Africa, the new artillery had to come from the local arms manufacturers. ${ }^{176}$ The new G5 towed 155-mm guns with a 40-km range, began from a programme started in 1978, while Armscor also developed a long-range base bleed round for the $140-\mathrm{mm}$ gun, extending its range to $21 \mathrm{~km} .{ }^{177}$ Another artillery development was the SADF's $127-\mathrm{mm}$ self-propelled multiple rocket launcher named Valkari, copied from an intact captured SovietBDM-21. During the late 1980s, the G6 155-mm self-propelled gun would ultimately prove itself without comparison to any Soviet artillery deployed in Angola.

\section{Engineering}

By 1975, the SA Engineering Corps bridging equipment included the best of British Army material, obtained through circumventing the arms embargo. ${ }^{178}$ But this equipment saw no Savannah service and improvisation with local materials like logs, only partially resolved problems with blown bridges. From the operation's outset, Comdt. Shylock Mulder, commander of 2 Field Engineering Regiment, was informed by Brig. Schoeman that he 
was to be the operation's engineering advisor and logistics officer. Mulder completed appreciations and discussed bridge building equipment needs with Van Deventer; but just before the Bridge 14 battle, Mulder was told combat bridging equipment would not be made available. Such was in accordance with political instructions that any loss of such equipment would be embarrassing and compromise future clandestine purchases. ${ }^{179}$ Local materials could not suffice for bridging the Pombuigi River during Battle Group Orange's attempted advance on Quibala, a situation confirmed by Mulder when he made a personal inspection of this site. ${ }^{180}$ Mulder believed that at least components of available combat bridging could have been flown into Angola and trucked to the required sites and that in the event of retreat, such could have been destroyed or withdrawn by the SADF. ${ }^{181}$

\section{Infantry/SADF Conscripts}

Training inadequacies amongst FNLA and Unita troops often rendered them unsuitable for advancing upon specific objectives under fire. Field commanders therefore appealed for more SADF infantry reinforcements and increasingly white infantry conscripts were deployed to the central front, particularly around Bridge 14, besides Battle-groups Orange and X-Ray. Novo Redondo was from late December reinforced with 5 SAI troops. ${ }^{182}$ A critical lesson for the infantry corps, proved not least by the high Unita/FNLA casualties at Ebo, was that for future offensive operations, infantry needed mobility and protection. This had to be associated with a combined arms mechanised battle-group. For this, the "soft-skin" transport of Unimogs and Bedfords were not robust enough, let alone adequate for transporting soldiers directly into frontline battlefield conditions. An effective infantry fighting vehicle (IFV) was urgently required.

There is also no doubt that during Savannah, half-trained Unita and Fapla infantry were used effectively as cannon fodder and took the heaviest "SADF" casualties, politically completely unacceptable had they been white troops. ${ }^{183}$ When trained infantry were necessary for frontal assaults on strengthened positions and casualties were likely, white troops could not be made available. Such was the situation for Battle-group Orange on 18 December, when Comdt. Dolf Carstens required a koppie occupied on the northern side of the Pombuigi River, so that bridge repair could be undertaken to continue the advance on Quibala. More than a company of 
trained infantry was available, but their use could not realistically be considered. ${ }^{184}$

An archival study and interviews focused on national servicemen's experiences might also assist in revealing more of conscripts' experiences, which as internet sites demonstrate, unsurprisingly diverge in detail emphasis, compared to regular soldiers who have been written about or interviewed regarding Savannah. Conscript sacrifices were not always appreciated: some national servicemen gunners - who had been in Angola since November 1975 - returning to Grootfontein between 24 January and 6 February 1976, were ordered to a far part of the base without any facilities and not allowed into the main base area, until they had shaved and cleaned. This insensitive pettiness reflects a lack of insight by some base officers at the ordeal the conscripts had been through. ${ }^{185}$

As virtually none of the SADF Savannah participants had any prior war experience, the casualties from some engagements must have been experienced by conscripts as particularly severe. On 11 November, an 11 Commando mortar team suffered eighteen national servicemen casualties from one enemy bomb; one of whom died later. ${ }^{186}$ Amongst the numerous fights at the different fronts, conscripts were killed or injured in action or died through accidents, ${ }^{187}$ while six were taken prisoner. Of the total 35 SADF Savannah fatalities about half were conscripts: ${ }^{188}$ Armour (7); Infantry (5), Artillery (3) Engineers (2). Clarity is still needed upon final numbers of SADF wounded; a figure of about 100 has been suggested, ${ }^{189}$ but not verified. The majority of wounded casualties would certainly have been national servicemen, although details still need to be located as to the extent of their injuries. Morale did depreciate at times amongst some white troops, indicated by occasions where they attempted to avoid combat. Breytenbach mentions two incidents: a paratrooper who temporarily deserted his comrades after the fighting around Catengue ${ }^{190}$ and a soldier from another unit who absconded in the wake of the Ebo disaster and attempted to reach SWA/Namibia. ${ }^{191}$ Within an artillery component supporting Battle-group Orange, Lt. Johan Potgieter encountered a battery where the gunners' organisation and morale appeared to have all but collapsed. ${ }^{192}$ 
There seems little doubt the Ebo disaster impacted negatively upon the national servicemen particularly. ${ }^{193}$ An urgent request was sent directly afterwards for each of an Afrikaans- and an English-speaking chaplain to be despatched to the front. ${ }^{194}$ Thereafter chaplains tended to be positioned at medical posts and approximately seventeen were eventually deployed during Savannah. ${ }^{195}$ Initially, there were only two doctors with the SADF in Angola and by 10 November, a senior physician was placed at Rundu, before casualties were passed onto 1 Military Hospital. When hostilities increased during late November, enhanced medical services were obviously required closer the battlefield. An existing hospital at Cela, seventy kilometres behind the front, was commandeered and medical personnel were dispatched including 6 medical officers and 9 ordinances. These were joined shortly afterwards by another 6 medical officers and 13 other medical personnel. These arrived just in time for the Ebo injured. When the first casualties arrived - 14 wounded South Africans and 22 Unita - the hastily assembled team was still not entirely ready. There was a shortage of blood plasma and initially no evacuation helicopter, with casualties being driven to Cela hospital on bad roads for five and a half hours after being wounded. Only from the following day was a helicopter made available.

Other patients later admitted to Cela hospital included 14 cases of "war exhaustion" and 11 cases of "shellshock"; there is no verification whether these were SADF or UNITA or both. ${ }^{196}$ From 12 to 15 December, a psychiatrist visited Cela and two categories of shellshock were identified: patients with hysteria, incapable of standing or giving their names, and a second group displaying symptoms of aggression and negativity, determined not to return to the front. The first group was treated with psychotherapy and rest; the second group was isolated because of their "aggressive and negative influence". ${ }^{197}$

It is a contested point whether, according to the Defence Act, the government had the legal right to deploy conscripts in Angola. Viljoen felt the government needed no such permission from national servicemen. ${ }^{198}$ However, as the SADF was entirely dependent upon conscripts and citizen force members, there was no other means by which Savannah could have proceeded. Permanent force Savannah veterans have recorded their respect for the national servicemen, who despite battle trauma at times overwhelming individuals, very often demonstrated courage and aggression. 
Lt. Johan Potgieter ordered troops to bury enemy bodies and body parts after the advance over Bridge 14 and explained how tough this was. Gen. Van der Westhuizen describes how, despite the troops' youth and limited training, they were well disciplined and performed well. ${ }^{199}$ Breytenbach's account of the paratrooper, who out of fear deserted his comrades, is one of the few recorded examples of a South African troop cracking under strain. ${ }^{200}$ Breytenbach was also critical of SSB members for allegedly leaving Unita troops in the lurch during one skirmish in the Bridge 14 vicinity. ${ }^{201}$ Internet sites where individual veterans post recollections, suggest many conscripts unsurprisingly experienced confusion and fear at being lurched into a war around issues that none could have comprehended properly. ${ }^{202}$

\section{Conclusion}

The SADF had undergone numerous changes since 1945, but its conventional war planning and much of its obsolete equipment were, by 1975, inadequate for the kind of operation that Savannah evolved into. The SADF was hampered by a lack of precise war aims, despite Defence Minister Botha enjoying the military's full confidence, ${ }^{203}$ while he and Vorster made a gross miscalculation in assuming American support would be sustained for an SADF intervention. ${ }^{204}$ SADF field commanders, caught up with the war's momentum, kept pushing forces forward, as at Ebo, in an attempt to accelerate the campaign according to their perceptions of the operational realities. By mid-December, the SADF advance had ground to a halt, consequential to their political instructions, equipment/manpower limitations and Cuban/MPLA resistance. The political objective of securing an anti-MPLA political victory was lost and the SADF could not confront swelling Cuban forces without their own massive reinforcements. Such would inevitably have sustained high numbers of white casualties, impossible to justify in terms of NP political priorities. And still, of course, there was no guarantee of a military victory. There was even less chance of achieving a sustainable political success through enforcing a Unita/FNLA government in Luanda via SADF coercion.

There is some truth to the Cuban claim that Ebo was a decisive battle, but from a South African perspective, Savannah's operational details remained closely guarded for years thereafter. Only in 1989 did a censored version of Spies's original manuscript appear in book form. ${ }^{205}$ Known 
exclusions included the evacuation of army personnel by the SAN after Roberto's aborted attempt to seize Luanda. Also omitted was the incident of a SAAF helicopter shot down in error on 4 January 1976 by SADF antiaircraft gunners, resulting in the death of Brig. J.D. Potgieter and four other SADF members. ${ }^{206}$

Savannah transformed into a brief but fierce conventional war, where for both sides, skilled artillery usage was fundamental to attaining or denying the enemy objectives. The SADF demonstrated marked resourcefulness and innovation in utilising the equipment and personnel at their disposal, for example, the often-successful deployment of Elands in a tank role, the determined far forward locating of artillery, and also the extraordinary initial advances by Task Force Zulu. There is no doubt that Bridge 14 was a well-fought SADF victory, demonstrating high professional soldier qualities amongst South African field commanders and courage from their conscript troops. These SADF successes, pro-Cuban/MPLA writers prefer to ignore or play down, carping instead about Ebo and the SADF withdrawal. Artillery was undoubtedly responsible for most casualties and in determining the outcome at the larger engagements: Novo Rondo, Ebo, Bridge 14 and the SADF's failure to advance beyond Quibala. Whether the SADF at this point in its history could have performed better by using more of its capacity is a matter of conjecture, but Breytenbach for one, believes it could have. $^{207}$

The Cubans proved themselves particularly skilled at building and holding defensive positions, but less so in mobile fighting within African bush terrain. ${ }^{208}$ However, their numbers and access to the best of Soviet hardware made them a potentially formidable foe against which the SADF urgently needed to modernise. Savannah had also demonstrated how quickly an enemy conventional force within Angola could be deployed into action, a warning to ensure the SADF markedly improved their conventional force mobilisation and combat capabilities. From 1976, the Ratel IFV appeared and artillery developments continued to produce the G5 and G6 guns, while 1977 witnessed the extension of national service to two years, to train and maintain combat troops over a longer period, in terms of assuring their battle proficiency and keeping adequate deployable troops under arms. From 1978, a permanent battle group, 61 Mechanised Battalion, was located in northern Namibia to face any future conventional threat. 
For all its political blunders, Savannah provided the SADF with a vital learning curve. In mid-1978, Operation Kwiksilwer took place - a full conventional war exercise intended to assess the army conventional war capacity, which coincided with the highly successful Ascension Day strikes against SWAPO bases in Angola, themselves conventional in operation.

1 The term 'Union Defence Force' was changed in 1957 to 'South African Defence Force'.

2 See interviews with Karen Brutents of the USSR Communist Party Central Committee and Fidel Castro on the CNN 24-part series Cold War (1998) by Ted Turner (Episode 17: Good guys bad guys). Castro and Brutents stress that the Cuban decision was entirely an independent one, not approved of by the USSR, but that the Soviets ultimately provided decisively large amounts of weaponry to the Cuban/MPLA forces.

3 The armed force of the MPLA was FAPLA - in English, the People's Armed Forces for the Liberation of Angola. In this article the term 'MPLA' is used throughout.

$4 \quad$ See WS van der Waals. Portugal's war in Angola 1961-1974. Rivonia: Ashanti, 1993, chapter 3, for one important reference outlining the supposed tribal affiliations of the different liberation movements. Such is markedly played down in pro-MPLA references such as P Gleijeses. Conflicting missions: Havanna, Washington, Pretoria. Alberton: Galago, 2003.

5 According to Van der Waals op. cit., p. 214, the white Angolan population by 1974 was around 335000 .

6 An observation attributed to Gen. Constand Viljoen, referred to in H Hamman. Days of the generals: The untold story of South Africa's apartheid-era military generals. Cape Town: Zebra Press, 2001, 15 and also quoted in H Giliomee. The Afrikaners. Cape Town: Tafelberg, 2003, 372.

7 Van den Bergh had ambitions for his agency to resemble a CIA-type operation, facilitating clandestine assistance to anti-communist forces, thereby maintaining police and secret security services ascendency over the military within internal government and state squabbles. See J Sanders. Apartheid's friends: The rise and fall of South Africa's Secret Services. London: John Murray, 2006, 48-49.

8 According to Deon Geldenhuys in The diplomacy of isolation. Johannesburg: MacMillan/SAIIA, 1984, 78-79, the first time the Department of Foreign Affairs heard about Savannah was via a protest note in early August 1975 from the Portuguese government, objecting to SADF troops advancing into southern Angola to guard the Ruacana and Calueque infrastructure.

$9 \quad$ J Barber \& J Barratt. South Africa's foreign policy: The search for status and security 1945-1988. Johannesburg: Southern Book Publishers, 1990, 192.

10 Ibid., pp. 190-196.

11 Sanders op. cit., p. 51, 53; Van den Bergh completely lost this battle; Botha remained well respected by the SADF High Command throughout the 1970s and 1980s.

12 Viljoen, when interviewed during the television series Grensoorlog, episode Magspel in Angola, produced by Linda de Jager for KykNet, 2008. 
13 Geldenhuys op. cit., p. 80.

14 J Geldenhuys. A general's story from an era of war and peace. Jonathan Ball, Jeppestown, 1995, 52.

15 For example, even the chief of the SA Navy, Vice Admiral James Johnson, was not informed and in early November 1975, when the navy's assistance was called upon to extract army personnel in northern Angola, Johnson was still ignorant of Savannah; being told by SAAF Chief Lt. Gen. Bob Rogers that he was not authorised to tell him (Johnson) about the operation "if he did not already know". Rear Admiral Chris Bennett: Presentation to the Cape Town Branch of the SA Military History Society presentation, January 2011. W Steenkamp. South Africa's Border War 1966-89._Gibraltar, 1989, 52.

17 This controversial period in the defence force is covered in RS Boulter. "FC Erasmus and the politics of SA defence 1948-59". PhD thesis. Rhodes University, 1997 and L Jooste. "FC Erasmus as Minister van Verdediging 1948-1959”. MA thesis. Unisa, 1995.

18 One of the best known of SADF officers during Savannah, Col. Jan Breytenbach, whom although not a World War Two veteran, was an SSB junior officer during the early 1950s and felt sufficiently negatively affected by the divisive atmosphere to join the line of resignations. See J Breytenbach. Eagle strike. Johannesburg: Manie Grove, 2008, 1-2.

19 According to Boulter op. cit., pp. 76-77, the $11^{\text {th }}$ Armoured Brigade was by 1950 well below its peacetime strength of 1300 officers and men. See pp. 46-71 for his assessment of the above described exercise.

20 Ibid., pp. 80-81.

21 Frans Erasmus's vain attempts regarding MEDO are documented in Boulter op. cit., pp. 114-147.

22 R Hyam \& P Henshaw. The lion and the springbok: Britain and South Africa since the Boer War. Cambridge: Cambridge University Press, 2003, 231, 246250.

23 RC Warwick. "White South Africa and defence 1960-68: Militarisation, threat perceptions and counter strategies”. PhD thesis. University of Cape Town, 2009, 38-42.

24 In spite of the controversies of leadership positions being reserved for political appointments, the SAAF's 2nd Squadron performed magnificently during the Korean War of 1950-1953. For one reference: D Moore \& P Bagshawe. South Africa's Flying Cheetahs in Korea. Rivonia: Ashanti, 1993.

25 New armour delivered between 1952 and 1956 included 200 Centurion tanks, 30 Comet tanks, 230 Ferret scout cars and 280 Saracen armoured personal carriers, all added to the existing UDF stocks of 97 Sherman tanks of varying types and 67 Honey light tanks, besides the available Marmon-Herrington armoured cars of the World War Two era. Steenkamp's draft and unpublished history of the SAAC was passed to me in May 2012. (Hereafter: Steenkamp, SAAC). There were also SAAF upgrades, with the 1956 delivery of 36 Canadian Sabre fighter jets.

26 An exception was that 35 refitted Centurion Mk 5 tanks were brought up to Namibia on standby during Savannah. See E Jordaan. "The role of South African armour in South West Africa/Namibia and Angola: 1975-1989”. Journal for Contemporary History 31/3. December 2006. 165. 
27 J Barber. South African foreign policy 1945-1970. Cape Town: Oxford University Press, 1973, 83-87.

28 Warwick op. cit., pp. 42-47.

29 Details of the 1960 SADF threat perceptions and counter strategies are covered in detail in Warwick op. cit., chapters 3 and 4.

$30 \quad$ Ibid., p. 42.

31 See TD Potgieter. "Corvette projects of the South African Navy and the printed media: Different government, different debate”. Based on a paper delivered at the XXIXth International Congress of Military History, War and the Media, Bucharest, Romania, 10-16 August 2003, 5-8. The plan named Project Taurus, involving the ordering of Corvettes from Portugal, was wracked with problems, which Potgieter ascribes to poor planning and execution of the project, demonstrating the SAN and Armaments Board's inexperience in being involved with designing a warship.

32 Warwick op. cit., pp. 268-273; A Wessels. "Duikbote in die Suid-Afrikaanse Vloot: Die eerste fase, 1970-2003. 'n Kort historiese evaluering (1): Agtergrond”. Journal for Contemporary History 30/2. September 2006.

33 Warwick op. cit., pp. 262-263.

34 See H Heitman. South Africa's armed forces. Cape Town: Buffalo Publications, 1990, 58 for the range of models.

35 Ibid.

36 Warwick op. cit., pp. 247-257.

37 Heitman op. cit., p. 58.

38 RS Lord. "SAAF fighter involvement in the Border War, 1965-1988". Journal for Contemporary History 31/3. December 2006. 251. Also see SAAF The Unofficial Website of the South African Air Force<http://www.saairforce.co.za/the-airforce/squadrons/14/85-combat-flyingschool

39 L Barnard. "Enkele aantekeninge oor die militêre struktuur en prosesse van die Suid-Afrikaanse Lugmag gedurende die grensoorlog”. Journal for Contemporary History 31/3. December 2006. 217.

40 L Barnard. "The South African Air Force's transport aircraft: Acquisition and utilisation during the Border War". Journal for Contemporary History 31/3. December 2006. 233-237. For a fuller outline of the SAAF's participation in Savannah, see L Barnard. "Die Suid-Afrikaanse Lugmag se optrede tydens Operasie Savannah - Relevant of 'n noodsaaklike ergernis?” Journal of Contemporary History 28/2. September 2003. 66-80.

41 See L Barnard. "Die Suid-Afrikaanse Lugmag se optrede in die teaters Angola en Rhodesië (circa 1966-74) as aanloop tot die Grensoorlog”. Journal for Contemporary History 31/3. December 2006.

42 SA Infantry Battalion moved to Bloemfontein in 1967, leaving Oudtshoorn to accommodate Infantry School. 3 SAI was established at Lenz in November 1961, moving to Potchefstroom in December 1968; from 1 January 1962, 4, 5 and 6 SAI were set up at Middelburg, Ladysmith and Grahamstown respectively, to accommodate increased ballotee conscript numbers.

43 See Warwick op. cit., pp. 408-430. 
44 L Scholtz. "Die ontwikkeling van die SA Leër in die Grensoorlog, 1966-1989". Journal for Contemporary History 31/3. December 2006. 113-114. During the early 1960s, the army issued 7.62-mm R1 automatic rifles and 7.62-mm light machine guns to its troops, consigning the .303 Lee-Enfields and Bren guns of World War Two era to the rural Commando units.

45 During the 1950s to early 1980s, 1 SSB had 'supportee' infantry (see Geldenhuys, A general's story ... op. cit., p. 57) for armour protection. According to Jordaan op. cit., pp. 168-169, this supportee infantry component consisted of one support troop for each armoured squadron.

46 Additional infantry units established were 7 SAI (Bourke's Luck), 8 SAI (Upington), 11 Commando (Kimberley) and the State President Guard. Armour conscripts were trained at 1 SSB (Bloemfontein) and artillery at 4 and later also 14 Field Regiments (Potchefstroom); engineers at 16 Field Regiment in Bethlehem.

47 W Steenkamp. "The citizen soldier in the Border War". Journal for Contemporary History 31/3. December 2006. 8. SADF official magazine Paratus of March 1976, pp. 19-21, emphasised the development of black troop training.

48 Ongulumbashi marked the very first time the SADF were formally, albeit secretly, involved in combat since 1945 . For one reference, see P Stiff. The silent war. Alberton: Galago, 1999, 36-37.

$49 \quad$ Ibid., pp. 22-33.

$50 \quad$ Ibid., pp. 20-21, 26; Warwick op. cit., pp. 280-281.

51 Stiff op. cit., pp. 17-91. In August 1972, Breytenbach’s group infiltrated Dar es Salaam via an SAN submarine, committing sabotage intended to destabilise President Nyerere's government.

52 On 29 August 1974, Lt. Freddy Zeelie, a 1 Reconnaissance Commando member, was the first SADF member killed in action during the 'Border War'.

53 For example, see Warwick op. cit., p. 281 and C Wilsworth. First in last out: The South African artillery in Angola 1975-1988. Johannesburg: 30 Degree South, 2010, photos facing p. 96.

54 A three-man SADF team visited France in 1965 to investigate the new 40-ton AMX-30 main battle tank, but it was considered too thinly armoured and its ammunition particularly expensive (Steenkamp, SAAC). Lt. Gen. Jack Dutton in his unpublished memoirs reported that he and other members of the team believed the SAAC's commitment must remain to the Centurion, which could be remounted with a 105-mm gun.

$55<$ http://www.saarmourassociation.co.za>

56 There was a separate armoured car regiment in Bloemfontein during the mid1960s.

57 1963, according to Heitman op. cit., p. 124.

58 Jordaan op. cit., p. 164.

59 Steenkamp, SAAC.

60 These included lengthening the nose to improve space and fitting locally produced 90-mm guns and engines. See Heitman op. cit., pp. 124-125.

61 Steenkamp, SAAC. By 1974, national servicemen and citizen force members manned 16 armoured regiments.

$62<$ http://en.wikipedia.org/wiki/ENTAC> 
63 Wilsworth op. cit., pp. 368-369.

64 Regarding pre-Savannah SADF cooperation with Israel concerning artillery, see Wilsworth op. cit., pp. 374, 378-379.

65 Ibid., p. 369.

6614 Field Regiment had been re-established in 1974.

67 The Sextons condition was indication of both obsolescence and neglect. See Wilsworth op. cit., p. 377.

68 By 1975, conscripts manned 4 and 14 Field Regiments, the School of Artillery and 3 Locating Battery, along with 143 Medium Battery at Walvis Bay. The citizen force had eight medium and field regiments along with two locating regiments. These were part of the SADF's conventional warfare structural reorganisation. See Wilsworth op. cit., pp. 22-23, 31. Steenkamp cites 19 artillery citizen force regiments existent by this time. (Steenkamp, "The citizen soldier ..." op. cit., p. 8.)

69 Wilsworth op. cit., p. 377. The envisaged reshaped SADF structure required 232 field (88-mm) and 84 medium (140-mm) guns. Available in 1973 were 183 and 52 respectively; Gen. Magnus Malan speaks of a shortage of SADF guns at Savannah's onset, see M Malan. My life in the SADF. Pretoria: Protea Book House, 2006, 124.

70 Wilsworth corresponded (22 June 2012) that besides gun shortages, there were even more significant deficiencies in supporting equipment numbers: fire control posts, reconnaissance vehicles, OP vehicles, etc.

71 Wilsworth op. cit., p. 36.

72 http://en.wikipedia.org/wiki/Green_Archer_(radar)

73 http://www.muckleburgh.co.uk/collection-images/cymberlinemortarlocatingradar-2.JPG

74 Correspondence: Wilsworth, 22 June 2012.

75 Steenkamp, SAAC.

76 Warwick op. cit., pp. 232-245.

77 Ibid., pp. 142-145.

78 Personality. 12 February 1970, “Our Top Brass”, (158-167).

79 Steenkamp explains Louw's plan being a conventional warfare task force consisting of a divisional combat group including tanks, with two (16 and 19) mechanised brigades and two (17 and 18) motorised brigades, spread between Bloemfontein, Potchefstroom and Oudtshoorn, supported by a communications and logistics area based at Pretoria. The divisional troops, together with 16 and 19 Mechanised brigades, would be located at Bloemfontein; 17 Motorised Brigade at Oudtshoorn and 18 Motorised Brigade in Potchefstroom. The "fist" of the divisional group structure was intended to be tanks, but there were only 103 Centurions, not all of which were operational, meaning at most, just one tank regiment. Quoting Steenkamp: “Louw's conceptual structure of forces either did not exist or were not combat-ready".

80 See Warwick op. cit., chapters 3 and 5.

81 Malan op. cit., pp. 89-95.

82 Stiff op. cit., pp. 21, 24.

83 Paratus. January 1972. 10. 
84 Communications with Brig. Gen. George Kruys: telephonically (25 June 2012) and correspondence (27 June 2012). The Ratel Infantry Combat Vehicle project began in 1974, after the reorganisation of the conventional forces.

85 Warwick op. cit., pp. 238-246.

86 Ibid., pp. 382-387.

87 I am in debt to Willem Steenkamp with whom I corresponded regularly during late May 2012 on the topic of "World War Two influences" on the 1960s and 1970s SADF.

88 Wilsworth op. cit., p. 373.

89 Scholtz op. cit., p. 115.

90 See CA Fraser. Revolutionary warfare: Basic principles of counter insurgency. (This was once an internal and restricted SADF publication, printed by the SADF's Survey and Printing Regiment.) It contains no date but all other information suggests this would be late 1967 or 1968.

91 Warwick op. cit., pp. 276-281.

92 SA Artillery personnel, for example, were being used as infantry in counterinsurgency operations, even after Savannah had started: see Wilsworth op. cit., pp. 25-27.

93 On the eve of Savannah, in late September to early October 1975, 81 Armoured Brigade conducted a conventional warfare training utilising a range of combat vehicles and equipment, most of it obsolete and never deployed during Savannah.

94 Air Force Chief Lt. Gen. Bob Rogers, Navy Chief Vice Adm. James Johnson and recently promoted Army Chief, Lt. Gen. Magnus Malan, with Maj. Genl. Constand Viljoen as Director of Operations and Maj. Gen. Fritz Loots as Director of Intelligence.

95 Hamman op. cit., pp. 8-9.

96 A perusal of the articles within Paratus during 1974 demonstrates that it is 'terrorism' in general and southern Africa specifically that receive attention. See June 1974, pp. 14-19 and August 1974, pp. 2-11.

97 JJ Collyer. The campaign in German South West Africa, 1914-15. Pretoria: Government Printer, 1937; JJ Collyer. The South Africans with General Smuts in German East Africa 1916. Pretoria; Government Printer, 1939. That said, some things obviously never changed; not least the great distances and poor or nonexistent road infrastructure.

98 Scholtz observes that during World War Two, the Abyssinian/Somalia battles of 1940 were for South African forces, the only period during the war when the opportunity existed for them to operate independently from other allied forces (Scholtz op. cit., p. 113). As a military history enthusiast, Jan Breytenbach at times refers to this distant link. See Buffalo Soldiers, Galago, Alberton, 2002, p. 62.

99 W Steenkamp. "The shaping of the South African soldier". Journal for Contemporary History 34/1. February 2009. 218-221.

100 According to Spies, SAS Johanna van der Merwe was already off the Angolan coast during August 1975. Rear Adm. Chris Bennett explained to the Cape Town branch of the SA Military History Society in January 2011 that during November 1975, the navy despatched a fully armed SAS Maria van Riebeeck to the Walvis Bay locality, awaiting any instructions. None were forthcoming from DHQ, 
although this was the period when Cuban troops were being transported by ship to Luanda.

101 For the most authoritative account of this operation, see C Bennett. Three frigates: The South African Navy comes of age. Durban: Just Done Productions, 2006.

102 See, for example, S du Preez. Avontuur in Angola 1975-1976. Pretoria: Van Schaik, 1989, 70-71.

103 Ibid.

104 According to Stiff op. cit., p. 105, based primarily upon 1987 interviews with Du Preez, SADF senior officers involved in Angolan discussions with the South African government believed Gen. Hendrik van den Bergh was dominating contacts with the CIA, the French Intelligence Service, Unita and the FNLA, annoying Defence Minister PW Botha in particular. The SADF generals felt intervention was necessary, in so far as supporting anti-communist forces FNLA and Unita. Van den Bergh did not think southern Angola would become a route for Swapo infiltration and that support should be limited to the FNLA. PW Botha persuaded Vorster to side with SADF intelligence Chief Gen. Du Toit. Already from October 1974, Unita was receiving limited South African arms along with further weapons supplied in February 1975.

105 Between the two camps, it was intended to train around 6000 black soldiers; see PL Moorcroft. African nemesis: War and revolution in southern Africa 19452010. London: Brassy's, 1990, 83. The SADF instructors formed the leadership element, including the platoon and company commanders, while other white troops either operated or were in charge of specialised weaponry: mortars, machine guns, Entac anti-tank missiles, armoured cars.

106 Around 100 MPLA dead, according to Steenkamp, South Africa's Border War op. cit., p. 44. Heitman op. cit., p. 204, speaks of two T-34 tanks destroyed; Du Preez op. cit. makes no mention of tanks.

107 A deduction made by Steenkamp, SAAC.

108 Gleijeses op. cit., p. 298.

109 Steenkamp, SAAC.

110 Enough internal chaos occurred after 25 April 1974 for anti-colonial Angolan forces to hunt down and kill Direccao Geral de Suguranca (DGS or Portuguese Security Police) personnel, including hundreds of Fleches - San previously enlisted into Portuguese Army Special Forces. The SADF anticipated their possible use in counterinsurgency operations against Swapo and after training they also formed part of Task Force Zulu. See Stiff op. cit., pp. 99-104.

111 Gleijeses op. cit., p. 301 states Zulu consisted out of "1 000 black Angolans and a smaller number of white South African soldiers". No figures are provided by Spies.

112 Malan op. cit., p. 118.

113 D Geldenhuys, cited in Gleijeses op. cit., p. 301, states the SADF had designed an operational plan of four phases, the last of which was to capture Luanda. L Scholtz, in "'n Strategiese en operasionele beoordeling van die Suid-Afrikaanse Weermag (SAW) se oorgrens-operasies in Angola, 1978-1988”. Journal of Contemporary History, volume 34, no.1, February 2009, 61-62, maintains the SADF were never instructed to occupy Luanda. Castro says Scholtz 
misinterpreted and overreacted by rapidly reinforcing Cuban forces. South African sources generally are in disagreement with Gleijeses.

114 Moorcroft op. cit., p. 85, says there remains conflicting figures as to the actual number of South African troops deployed. Most South African sources speak of up to 2000 men rising to a maximum of 3000 , while some foreign writers suggested 5000 to 6000 . Johnson and Martin suggest 12000 (see P Johnson \& D Martin. Frontline South Africa. Peterborough: Ravan, 1989, 121).

Foxbat now consisted of three Unita companies; 22 Eland 90s, two 106-mm recoilless guns, four Unita-manned 81-mm mortars, three Entac teams and four .50-calibre Browning heavy machine guns, together with a light aircraft for observation.

Du Preez op. cit., p. 57, says he was a colonel. Gleijeses makes no mention of this officer's death.

117 Steenkamp, SAAC.

118 Nortje, P., 32 Battalion, The Inside Story of South Africa's Elite Fighting Unit, Zebra Press, Cape Town, 2003, pp. 15-23.

119 According to Breytenbach, Buffalo Soldiers op. cit., p. 66, these had been trained separately at Serpa Pinto by Maj. Frank Bestbier. Also see Heitman op. cit., p. 205.

120 Breytenbach, Buffalo Soldiers, op.cit., pp. 124-125. These included Alpha, Bravo, Foxbat and X-Ray. Breytenbach remarks angrily upon the paratrooper deployment, as ordered by the SADF 'General Staff', accusing them of misusing a valuable resource of "highly trained and motivated" soldiers by deploying them as "armed guards".

121 Ibid., pp. 64-65.

122 Spies op. cit., p. 117. Breytenbach, Buffalo Soldiers op. cit., p. 76. According to Gleijeses op. cit., p. 309, some 35 to 40 Cuban instructors were involved and suffered heavy casualties. Gleijeses believes Diaz Arguelles, the Cuban commander of their expeditionary force, had initially underestimated the threat posed by Zulu. Although Foxbat had already encountered Cubans defending the routes to Novo Lisboa, Gleijeses suggests Arguelles had not yet been aware that South African troops were involved. Gleijeses op. cit., p. 324.

All casualties were national servicemen from 11 Commando. See Spies op. cit., pp. 125, 128-129.

126 See Breytenbach, Buffalo Soldiers op. cit., pp. 104-106; although according to Wilsworth op. cit., pp. 54-56, it was already clear to the SADF gunners that their 88-mm weapons were well outranged by the BM-21 122-mm rocket launchers.

127 Du Preez op. cit., pp. 95-96.

128 Ibid., pp. 97-98. One conscript was killed and another SADF member injured.

129 Heitman op. cit., pp. 205-206, speaks of 210 enemy troops killed, 96 wounded and 56 captured for the loss of five dead (one SADF) and 41 wounded (20 SADF). Moorcroft op. cit., p. 86, writes that a Cuban-supporting journalist described Zulu's advance as a "Sunday drive", where opposition had been pushed aside with "contemptuous ease". Certainly SADF-orientated accounts are written in that tone 
130 According to Jordaan op. cit., p. 165, the crews trained for deployment in August 1975 had "significantly better training than other intakes before and shortly after them".

131 Gleijeses op. cit., p. 302. The general gist of pro-MPLA/Cuban sources utilised by Gleijeses and interviews on the CNN television series Cold War (1998) is of a desperate MPLA, who viewed the SADF-led column as unstoppable, causing severe Cuban and MPLA casualties; hence their jubilation at the Ebo battle (see Cold War episode 17 [Good guys bad guys] - interview with Lucio Lara, General Secretary of the MPLA).

132 Moorcroft op. cit., pp. 87-88. Gleijeses op. cit., p. 394, explains that if Porto Amboin fell (which was just $160 \mathrm{~km}$ south of Luanda), Zulu could split with one group advancing towards Luanda and the other towards Dondo (north of Quibala), which controlled the capital's electricity supply. 132; an account repeated in Breytenbach's other books on 32 Battalion, whereby the SADF at Ebo retreated in haste. Breytenbach is also emphatic that Cuban and MPLA troops walked through the battlefield afterwards and shot the remaining Unita wounded. Gleijeses op. cit., pp. 308-311.

Breytenbach, Buffalo Soldiers op. cit., p. 112. 1 Military Area based at Rundu reverted to the north of Namibia; 2 Military Area comprised southern Angola under Schoeman; 3 Military Area was northern Angola, but the FNLA's defeat outside Luanda effectively ended all SADF presence and involvement in this region.

Steenkamp, South Africa's Border War op. cit., p. 54.

Gleijeses op. cit., p. 326. Rene Hernandez, a Cuban commander interviewed on the CNN Cold War series, episode 17, explained how Ebo was the most decisive battle for the Cubans. He is emphatic that if Cuban defence here had broken, it would have been very difficult preventing the SADF from reaching Luanda.

See Du Preez op. cit., pp. 127, 130-131.

Gleijeses op. cit., pp. 316-317. Holm's force drove directly into a well-prepared ambush. Most of the Ebo battle thereafter involved attempts to rescue the armour crews and recover the armoured cars. The supporting FNLA and Unita infantry took heavy casualties.

Figures seem to range between five to eight armoured cars lost.

See Wilsworth op. cit., pp. 58-65: The pilot, $2^{\text {nd }}$ Lieutenant Keith Williamson, directed the artillery fire, but his co-ordinates were dismissed by the artillery commander, who thought them incorrect. Wilsworth op. cit., p. 63, points out that the 88-mm artillery had no delay-acting fuses or any other type of ammunition to mark where they were firing so that accurate corrections could be made.

As interviewed in the 2009 Grensoorlog television series.

Gleijeses op. cit., p. 317. A monument to Diaz Arguelles can be located on Google Earth at 11'00' 52.69 S 14' 47’ 2002 E.

Steenkamp, SAAC.

See Gleijeses op. cit., pp. 317-320.

\section{. cit., pp. 317-320.}

Spies op. cit., pp. 193-194. 
147 Ibid., pp. 194, 197. It is not clear whether the squadron and battery numbers were entirely up to strength, but if they were, there would be around 44 Elands and 24 guns, both $88-\mathrm{mm}$ and $140-\mathrm{mm}$, present on the central front; the biggest concentration of SADF strength at any point during Savannah, besides a battery of 20-mm anti-aircraft guns around Cela.

G Shaw. The Cape Times: An informal history. Cape Town: David Phillip, 1999, 260-266; Anthony Heard was the editor in 1975 to 1976 and met Vorster in midNovember, by which time Task Force Zulu had completed its advance up to Novo Redondo and moved west to join Foxbat. Just before the Ebo engagement, Vorster revealed to Heard that South African troops were in Angola, assisting Unita "to take Luanda, and thereby win the civil war".

Paratus. January 1976. 10-14; September 1975. 24-28; March 1976. 8-11; April 1976. 17-24.

150 Moorcroft op. cit., p. 91, speaks of 200 Cuban and 200 MPLA troops killed for four SADF dead. Captured weaponry included 10 76-mm guns, 22 120-mm mortars and 5 BM-21s.

Steenkamp, SAAC. Gleijeses op. cit., p. 321, concedes Cuban losses but says: "not only did the [SADF] not reach Quibala, ten miles north of Catofe, but they did not even enter Catofe". Gleijeses points out that Du Preez agrees on this point, in stating that landmines and 122-mm launchers forced Foxbat to take cover as FAPLA/Cubans deployed to new positions with heavier weapons. However, Du Preez op. cit., pp. 172-173, states that three weeks later, after Foxbat was reinforced, mines were lifted and under SADF artillery bombardment, the FAPLA/Cubans left Catofe while a Foxbat advance guard entered the town. Quibala was now just $20 \mathrm{~km}$ away, but just out of $140-\mathrm{mm}$ guns' range. Further advances north were hindered by more mines and 122-mm rockets, with the Unita infantry continuing to flee from such bombardments.

Du Preez op. cit., p. 172.

153 Steenkamp, SAAC, remarks upon how these official rotations of command were not always well timed to the SADF's advantage, considering this example as one typical occasion.

154 Heitman op. cit., pp. 207-208. Orange consisted of a Unita infantry battalion, a company of 2 SAI infantry, one armoured car squadron and was later supported by 140 -mm artillery. Steenkamp, SAAC.

Geldenhuys, The diplomacy of isolation op. cit., p. 81.

Gleijeses op. cit., pp. 341-342.

A comment originally attributed to Eschel Rhoodie; see Sanders op. cit., p. 53.

Gleijeses op. cit., pp. 341-345.

See Malan op. cit., p. 133 for just one example.

See Spies op. cit., p. 304, where he specifically mentions the artillery conference of 23 to 25 February and the need for improved vehicle manoeuvrability on "Africa terrain", comparisons between SADF weaponry capabilities and the enemy's and discussions on how required changes could be rapidly attained. Spies's full list included: personnel; intelligence; operations; logistics; medical services; civic action; ground to air cooperation; infantry; vehicles; armour; artillery; engineers; signals; technical services; organisation; more rapid, effective 
preparation; shelter; and storage under all weather conditions, besides the chaplain's role.

Geldenhuys A general's story ... op. cit., p. 56; he makes this point but provides no specific details, besides some references to artillery.

See Spies op. cit., p. 107 and his further comments in the footnotes on p. 110.

See Breytenbach, Buffalo Soldiers op. cit., p. 119.

See Jordaan op. cit., pp. 166-168 for a more detailed account of Eland problems.

Du Preez op. cit., p. 182.

Steenkamp, SAAC.

Heitman op. cit., pp. 125-126.

Steenkamp, SAAC.

Wilsworth op. cit., pp. 370-372.

Du Preez op. cit., p. 183.

Wilsworth op. cit., pp. 370-372.

Ibid., pp. 374-375.

Correspondence: Wilsworth, 22 June 2012.

Ibid., p. 142.

Ibid., pp. 272-273.

Heitman op. cit., p. 128.

Telephonic interview: Kruys, June 2012.

Correspondence: Mulder, 26 June 2012.

Du Preez op. cit., p. 181.

Telephonic interview: Mulder, 1 July 2012.

Steenkamp, SAAC.

It is a grim reality that black troops were considered expendable; this regarding both the SA government and SADF attitudes of the time, although some SADF commanders such as Breytenbach fully acknowledged the loyalty and bravery of his black troops; hence his protecting them by insisting their repatriation as a unit back to Namibia, the genesis of 32 Battalion.

Du Preez op. cit., pp. 182-183.

Wilsworth op. cit., p. 135.

See Spies op. cit., pp. 125, 128-129. The incident is described more vividly in Du Preez op. cit., pp. 93-94.

See Du Preez op. cit., p. 99.

According to Malan op. cit., p. 140, of the 35 Savannah fatalities, 18 were national servicemen and 17 permanent force members; figures confirmed by a scrutiny of Spies's list and their force numbers (see Appendix A in Spies).

A Seegers. The Military in the making of modern South Africa. London: IB Tauris, 1996, 222.

Breytenbach, Buffalo Soldiers op. cit., pp. 78-79.

Ibid., p. 114.

Wilsworth op. cit., p. 115 writes: "there was no or very little ammunition. What was there was left lying around the gun position unprotected against the sun and the rain. Gun tractors were parked between the guns making a 'juicy' target; no trenches or foxholes existed”... rations were in short supply, the gun position was untidy and disorganised and most importantly, the troops morale was extremely low. All this could be ascribed to a battery commander and battery sergeant- 
major ... although qualified, were unsuited for the job and had not bothered to carry on training these only partially trained troops.”

Ibid., p. 165. The Chaplain-General was also not privy to the planning and execution of Savannah.

A Wessels \& I Bredenkamp. "Military chaplaincy in the South African Defence Force during the Namibian War of Independence, 1966-1989". Journal for Contemporary History 34/1. February 2009. 230.

Considering the racial attitudes prevalent at that time and the particular concerns for white troops firstly, it is more than likely most or all of these cases were white.

Spies op. cit., pp. 162-163.

See Giliomee op. cit., pp. 573-574. According to the Truth and Reconciliation Commission, no provision was made in the 1957 Defence Act for the deployment of non-voluntary forces (conscripts) beyond South Africa's borders. In January 1976, the South African government passed legislation sanctioning non-voluntary South African forces' deployment outside of the Republic's borders, made retroactive to $\quad$ August $1975 . \quad$ See http://www.stanford.edu/class/history48q/Documents/EMBARGO/2chap2.htm

Christopher Saunders notes that the Commission was neither able to access any SADF files on Savannah for no clear reason given nor obtain any official documentation from Angola. See C Saunders. "South Africa in Namibia/Angola: The Truth and Reconciliation Commission's account”. In G Baines \& P Vale (eds), Beyond the Border War: New perspectives on Southern Africa's Late-Cold War conflicts, UNISA, 2008, 272-273.

Grensoorlog. Episode Brug 14.

Breytenbach, Buffalo Soldiers op. cit., pp. 78-79.

Breytenbach, J., They live by the sword, Lemur Books, Alberton, 1990, pp. 6061.

See for example "Dave Hill" recollections at http://papatroop.tripod.com/Brigadier\%20Potgieter.htm and Mark Goller at http://bethlehemssappers.blogspot.com/2010/09/bridge-14-and-op-

savannah.html?zx=63b7b86c54411139. These sites can be problematic in terms of verification of detail, but they do provide some window upon individual soldiers' recollections of details and feelings. Also see http://papatroop.tripod.com/some_men_did_not_return_home.htm

203 Even Breytenbach, the most critical of SADF veterans who has expressed views on Savannah, is defensive of PW Botha. See Breytenbach, Buffalo Soldiers op. cit., p. 123.

204 According to Moorcroft op cit., p. 96, Vorster must have been warned by Van den Bergh, who had sufficient information upon which to base his perceptions that the South African government could in no way be guaranteed American support.

205 See I van der Waag \& D Visser. "War, popular memory and the South African literature of the Angola conflict”. Journal for Contemporary History. 34/1. February 2009. 124. 
206 Malan op. cit., p. 131, concluded this incident was a consequence of "ground fog and lack of proper procedures". Also see: Barnard Noodsaaklike ergernis op. cit., p. 76 .

207 Breytenbach is scathing in his condemnations of both politicians and senior SADF staff for not making more use of the SADF's resources. See Buffalo Soldiers op. cit., pp. 123-127, where Breytenbach makes a series of criticisms as to how the South African government and SADF conducted the campaign.

208 Steenkamp, South Africa's Border War op. cit., p. 48. 